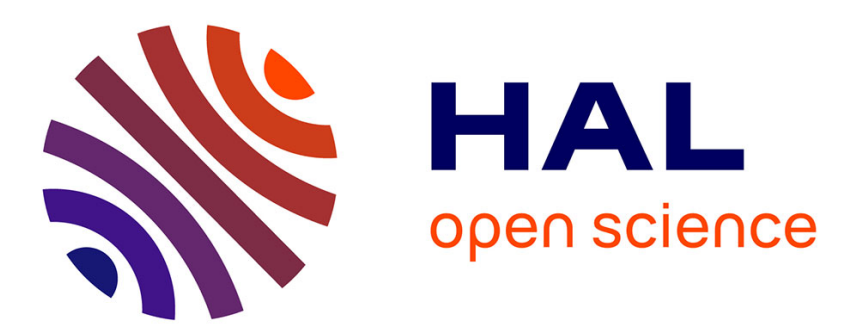

\title{
Chasing water: Diverging farmers' strategies to cope with the groundwater crisis in the coastal Chaouia region in Morocco
}

Adnane Berahmani, Nicolas Faysse, Mostafa Errahj, Mohamed Gafsi

\section{- To cite this version:}

Adnane Berahmani, Nicolas Faysse, Mostafa Errahj, Mohamed Gafsi. Chasing water: Diverging farmers' strategies to cope with the groundwater crisis in the coastal Chaouia region in Morocco. 2011. cirad-00872500

\author{
HAL Id: cirad-00872500 \\ http://hal.cirad.fr/cirad-00872500
}

Preprint submitted on 13 Oct 2013

HAL is a multi-disciplinary open access archive for the deposit and dissemination of scientific research documents, whether they are published or not. The documents may come from teaching and research institutions in France or abroad, or from public or private research centers.
L'archive ouverte pluridisciplinaire HAL, est destinée au dépôt et à la diffusion de documents scientifiques de niveau recherche, publiés ou non, émanant des établissements d'enseignement et de recherche français ou étrangers, des laboratoires publics ou privés. 


\title{
Chasing water: Diverging farmers' strategies to cope with the groundwater crisis in the coastal Chaouia region in Morocco
}

\author{
Adnane Berahmani ${ }^{1}$, Nicolas Faysse ${ }^{2,3}$, Mostafa Errahj $^{3}$ and Mohamed Gafsi ${ }^{4}$ \\ ${ }^{1}$ Tafilalet Regional Agricultural Development Authority, Errachidia, Morocco \\ ${ }^{2}$ CIRAD, G-EAU Research Unit, National Agricultural, College of Meknès, Morocco \\ ${ }^{3}$ ENA Meknes, Department of Development Engineering, Meknes, France \\ ${ }^{4}$ National School for Agronomic Education (ENFA), Rural Dynamics Research Unit, Toulouse, France
}

This is the pre-peer reviewed version of the article with the same title, which has been published in final form at http://onlinelibrary.wiley.com/doi/10.1002/ird.1673/full

\section{SUMMARY}

In many developing countries where agricultural groundwater use led to aquifer overexploitation, direct control over farmers' groundwater use is difficult to implement. This calls for the set up, at least in the short term, of indirect policies, whose efficiency will depend on farmers' strategies. The different strategies adopted by farmers to cope with groundwater crisis are analyzed in the Chaouia Region in Morocco, where intensive agricultural groundwater use for the past fifty years has led to seawater intrusion in the seashore part and falling groundwater levels further inland. First, strategies may be based on 'chasing' groundwater, by deepening boreholes, bringing fresh water in sufficient quantity to the farms or renting fields in areas with sufficient fresh groundwater, so as to maintain a water-intensive farming system. Second, strategies, that may be designated as adaptive, entail adapting the farming system to the water available on-farm given existing hydraulic infrastructures and may be considered as more sustainable with regards to water resources. Most of analysed strategies were not in the same time economically and environmentally sustainable. Possible policies to achieve economically and environmentally sustainable activities differ not only in the difficulty to implement them, but also in the types of farms likely to benefit from them.

KEY WORDS: adaptation; farm strategy; groundwater; Morocco; salinity 


\section{RESUME}

Dans de nombreux pays en voie de développement où l'usage agricole des eaux souterraines a conduit à une surexploitation des nappes, il est difficile d'organiser un contrôle direct de l'usage par les agriculteurs des eaux souterraines. Il est alors possible de mettre en place à court terme de politiques influençant de façon indirecte cet usage, mais leur efficacité dépendra des stratégies des agricultures. Les différentes stratégies adoptées par les agriculteurs pour faire face à une crise d'accès à l'eau souterraine ont été analysées dans la région de la Chaouia côtière au Maroc. Dans cette région, l'usage agricole intensif de l'aquifère a mené à l'intrusion saline dans la partie littorale et une baisse des niveaux piézométriques dans la partie interne de l'aquifère. Des stratégies, que l'on peut qualifier de 'chasse' à l'eau souterraine, se fondent sur un approfondissement des forages, l'amenée d'eau de l'extérieur vers l'exploitation agricole, et la location de parcelles dans des zones riches en eau souterraine douce. Ces stratégies permettent aux agriculteurs de maintenir des systèmes de production nécessitant une forte consommation d'eau douce. D'autres stratégies, que l'on peut qualifier d'adaptatives, visent à adapter les systèmes de production à l'eau disponible sur l'exploitation compte-tenu des puits et forages existants. La plupart des stratégies analysées ne sont pas durables simultanément du point de vue économique et environnemental. Les politiques publiques pour favoriser de telles activités durables à la fois d'un point de vue économique et environnemental, diffèrent non seulement quant à leur difficulté de mise en œuvre, mais aussi quant aux types d'exploitations agricoles qui seront le mieux en mesure d'en bénéficier.

MOTS CLES: adaptation; eau souterraine; Maroc; stratégie des agriculteurs; salinité

\section{INTRODUCTION}

The increasing use of groundwater has enabled considerable agricultural development since the 1970s. However, groundwater use has also often had impacts on natural resources, such as drops in groundwater tables, groundwater salinization (for instance in the case of seawater intrusion due to overexploitation of coastal aquifers), and/or salinization of soils, all of which have a direct impact on the sustainability of irrigated agriculture (Giordano, 2009). In many developing countries, the use of agricultural groundwater is difficult to control, due to the high number of farmers and their informal use of water, and to the lack of institutional and financial 
capacities. Moreover, there are fewer and fewer opportunities to supply surface water because catchment basins are themselves increasingly over-allocated.

Given these limitations, 'second-best' public policies may attempt to: 1) provide incentives or indirect means to reduce the use of groundwater; 2) help famers adapt to the decrease in the quality and quantity of groundwater. Such policies may act on both the water demand (e.g. through improved irrigation techniques) and the supply (e.g. by improving water harvesting or using waste water) (Qureshi et al., 2010). In India, local institutions built water harvesting infrastructure and provided farmers with low rate credits to invest in agriculture after drought periods that led to groundwater decline (Mudrakartha, 2007). The government of Gujarat provided a separate electric power supply for groundwater pumps that enabled it to control pumping hours and thus limit withdrawal (Shah, 2009). Such policies may combine actions that are 'water-focused' with others that may have little direct relation with water resources, such as providing non-agricultural employment opportunities (Moench, 2007). Since these policies are based on incentives or indirect means and do not directly control farmers' groundwater use, their efficacy in terms of reaching the two above-mentioned goals, depends on farms' characteristics and farmers' strategies.

In India and Nepal, the strategies used by farmers facing groundwater scarcity were found to be: 1) an attempt to diversify income sources away from water-dependent, agricultural forms of livelihood; 2) an attempt to increase access to water, particularly secure sources of water for domestic and livestock use, through water-harvesting activities, by drilling ever-deeper wells and by purchasing water through informal markets; 3) when all else failed, coping through reduced water consumption (Moench, 2007). Farmers may revert to rainfed farming either because of lack of capital to deepen boreholes (e.g. in India, Mukherji, 2006) or because of too high pumping costs (e.g. in the US, Oweis et al., 1999). Groundwater depletion increased the heterogeneity among farms in Gujarat, as well-off farmers were more able to invest into deep boreholes than small-scale farmers (Prakash, 2005). However, links between analyses of such farmers' strategies and discussion of possible policies to tackle the groundwater crisis are rare.

In this article, first, we analyze the different strategies adopted by farmers to cope with the growing groundwater crisis and, second, we discuss to what extent our results may support the design of public policies to help farmers adapt to groundwater stress and in the same time reduce groundwater use. The study was carried out in the coastal Chaouia Region in Morocco. In Morocco, the agricultural use of groundwater was multiplied by three between 1970 and 1996 (Bahir and Mennani, 2002). Moroccan farmers increasingly rely on groundwater, even within irrigation schemes (Kuper et al., 2012) and overexploitation of the aquifers has been identified in many areas including the Souss, Tadla, Berrchid and Saiss regions (Bekkar et al., 
2009). The coastal Chaouia aquifer is of interest to assess available opportunities to face groundwater overdraft in Morocco for two reasons. First, the area, although small, includes one zone where the groundwater has become saline and another where it has become scarce. Hereafter, these two issues are jointly referred to as 'groundwater stress'. Second, historically, it is one of the first regions in Morocco affected by groundwater stress and it is thus possible to analyze two decades of how farming systems have faced this constraint.

The study was carried out as an initial assessment in the framework of the Aquimed project. This project aimed to develop methods to support stakeholders in undertaking foresight analyses to assess interrelated agricultural development and groundwater management strategies in coastal regions involving intensive groundwater use, taking into account climate change.

\section{METHODOLOGY}

Case study

The $1200 \mathrm{~km}^{2}$ coastal Chaouia aquifer is located in the Doukkala Region south-west of Casablanca, and is delimited by the Oum Er Rbia River in the west, the Bouskoura River in the east and by non-permeable rocks in the south. The $700 \mathrm{~km}^{2}$ study area is situated in the western part of the aquifer, between the towns of Azemmour and Bir Jdid, since much less irrigated farming takes place in the eastern part of the aquifer (Figure 1). The aquifer is filled almost only from rain infiltration (on average, $383 \mathrm{~mm} / \mathrm{yr}$ ). In the study area, apart from the small Wawra River, no other rivers supply water to the aquifer, which limits opportunities for rainwater harvesting. The aquifer level and salinity rates are very sensitive to rainfall patterns, resulting in marked differences in measurements between the rainy season - winter- and the dry season summer (Younsi, 2001).

The groundwater was first used in the 1960s for irrigation of citrus and vegetables. The area dedicated to rainfed crops decreased with an increase in the number of wells and later in boreholes. In the 1980s, the region experienced a golden age. Called the 'California of Morocco', it provided the bulk of vegetables for export to Europe. The International Trade Office parastatal organized the production and export of these vegetables. Groundwater use increased very rapidly with the shift towards more intensive use of land, which was accelerated as inheritance processes reduced the size of farm land. Seawater intrusion, which was first observed in the 1980s, was the result of simultaneous groundwater overexploitation and drought. In the 1990s, water salinity problems were compounded by the end of the International Trade Office intervention, as well as the spread of pests such as the white-fly borne tomato yellow leaf curl virus. Further inland, since the beginning of the 2000s, many farmers have been 
limited in their activities due to falling groundwater levels. The water deficit is estimated at 10 million cubic metres per year for the whole aquifer (Table I).

Table I. Groundwater balance of the coastal Chaouia aquifer $\left(\mathrm{Mm}^{3} / \mathrm{yr}\right)$

\begin{tabular}{llr}
\hline Recharge & Rainfall infiltration & 30 \\
\hline & Alimentation from the South border & 5.5 \\
& Recharge from Oum Er Rbia River & 0.1 \\
& Seawater intrusion & 1.1 \\
& Total recharge & 36.7 \\
Discharge & Outflow to the ocean & 11 \\
& Abstraction by wells and boreholes & 30.6 \\
Total balance & Evaporation & 5.6 \\
& Total discharge & 47.2 \\
\hline
\end{tabular}

Source: Bouregreg-Chaouia Catchment Management Agency (2010)

Four main areas can be delimitated based on the groundwater status (Figure 1). In zone Z1, which is located close to the coast, seawater intrusion led to groundwater salinization and conductivity has reached $10 \mathrm{mS} / \mathrm{m}$ in some areas (Fakir et al., 2001; Moustadraf et al., 2008). In zone Z2, the groundwater level has decreased and farmers currently face water scarcity. In zone $\mathrm{Z} 3$, groundwater has become saline but this is due to the presence of salts in certain layers of the aquifer, not to seawater intrusion (Fakir et al., 2001). In the study area, the soil is generally sandy, so most of the salt brought by irrigation is washed down during rainfall events. Finally, in zone $\mathrm{Z4}$, farmers have still access to groundwater that is sufficient in terms of quantity and quality. The limits between each zone are not precise and the zones may overlap: in parts of zone $\mathrm{Z1}$ adjacent to zone $\mathrm{Z} 2$, farmers face both water scarcity and salinity problems, especially in summer. Apart from a very limited number of boreholes for drinking water in rural communities, all the groundwater withdrawn is used for the irrigation of approximately 6,500 ha. In 1995, an exhaustive survey assessed 1,089 wells in the whole aquifer area (Fakir et al., 2001). No other survey was undertaken later on.

In the 1980s, local authorities tried to control the drilling of boreholes but when a series of droughts occurred, they considered the short-term salvaging of the local economy to be more important and stopped such attempts. Two catchment management agencies are responsible for the monitoring and management of the aquifer (one for the part west of Bir Jdid, the other for the eastern part). In practice, these organizations are not active in the area apart from monitoring 
piezometric levels and salinity rates. In 2010, the drilling and use of boreholes were uncontrolled.

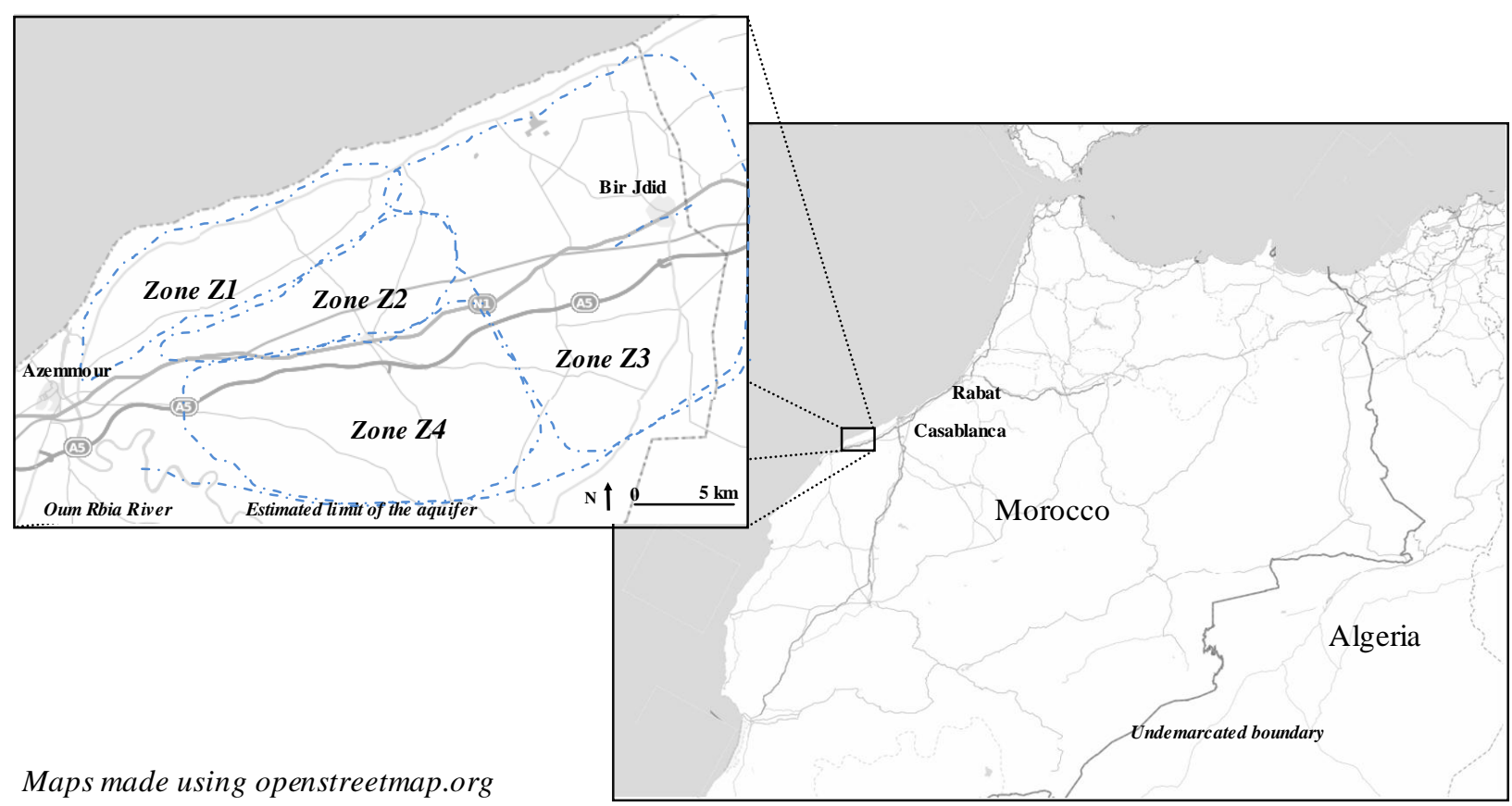

Figure 1. The part of the coastal Chaouia Region under study.

\section{Method and data collection}

Farmers' strategies can be defined as a long-term orientation, which guides the choice of agricultural and other activities of the household, as well as the mobilization of means necessary to achieve the objectives fixed by the farmer (Gafsi, 2007). Studying farming practices and farmers' objectives may help understand these strategies. Thirty-nine farmers were interviewed in the two zones regarding: 1) how their farms had changed in the past and reasons for these changes; 2) the main characteristics of their farms, the way they access water and their cropping pattern; 3) the activities of their sons and their projects for the future. The analysis focused on zones $\mathrm{Z1}$ and $\mathrm{Z} 2$, where groundwater use is intensive and where farmers face problems with respect to the quantity and quality of available groundwater.

\section{RESULTS}

\section{Types of farms}

Farms were classified according to their cropping patterns and the area they farmed, on both owned and rented land. Type A farms cultivated more than 20 ha. In irrigated areas of Morocco, 
such farms are generally considered to be large-scale farms. All Type A farms grew vegetables and had some greenhouses (Table II shows the main characteristics of each type). Type A' farms were specialized: two farms grew potatoes, with good control over marketing, and one grew flowers. Among vegetable farmers with less than 20 ha, Type B farms produced part of their vegetables in an intensive way in greenhouses, particularly tomatoes, cucumbers and courgettes. One of these farmers had adopted a 'transhumant' strategy: he rented land in the central part of the aquifer, but also invested in land he owned close to seashore when rainfall had been heavy during winter. Type $\mathrm{C}$ farms had less intensive cultivation practices, with openfield production of vegetables, mainly potatoes, carrots and tomatoes. Finally, type D farms did not grow vegetables but focused on cereals and fodder. Apart from Type B farms, which were mainly found in zone Z2, the other types of farms were more or less evenly distributed between areas where water is scarce and areas where the water is saline. According to many studies in Morocco, specialized farming systems and the farming systems using greenhouses (Types A, A' and B) are ranked first in terms of added value per ha, with open-field vegetable based systems (Type C) in an intermediate position, and cereal/fodder based farming systems (Type D) in last position. Farm equipment, such as tractors or greenhouses, was classified on a scale of 1 (no equipment) to 4 (fully equipped). Average equipment levels of Type A, A', B, C and D farms are ranked in decreasing order. Around $90 \%$ of the total irrigated area of the study was equipped with drip irrigation systems. Types A, B and C farms bred cattle for both milk and meat.

Table II. Main average characteristics of farm types

\begin{tabular}{|c|c|c|c|c|c|c|c|c|c|c|c|c|}
\hline \multirow{2}{*}{$\begin{array}{c}\text { Typ } \\
\text { e }\end{array}$} & \multirow{2}{*}{$\begin{array}{l}\text { Numbe } \\
\text { rs of } \\
\text { farms } \\
\text { in the } \\
\text { survey }\end{array}$} & \multirow{2}{*}{$\begin{array}{c}\text { Overall } \\
\text { farmed } \\
\text { area } \\
\text { (ha) }\end{array}$} & \multirow{2}{*}{$\begin{array}{l}\text { Rente } \\
\mathrm{d} \\
\text { land } \\
(\%)\end{array}$} & \multirow{2}{*}{$\begin{array}{l}\text { Level of } \\
\text { equipme } \\
\text { nt }\end{array}$} & \multirow{2}{*}{$\begin{array}{l}\text { Number of } \\
\text { wells and } \\
\text { boreholes } \\
\text { (in both } \\
\text { owned and } \\
\text { rented land) }\end{array}$} & \multirow[t]{2}{*}{ Cattle } & \multicolumn{6}{|c|}{ Cropped area (\% of total farmed area) } \\
\hline & & & & & & & $\begin{array}{c}\text { Tomat } \\
\text { o }\end{array}$ & $\begin{array}{c}\text { Potat } \\
\text { o }\end{array}$ & $\begin{array}{c}\text { Other } \\
\text { vegetabl } \\
\text { es }\end{array}$ & $\begin{array}{c}\text { Whe } \\
\text { at }\end{array}$ & $\begin{array}{c}\text { Fodd } \\
\text { er }\end{array}$ & $\begin{array}{l}\text { Other } \\
\text { crops }\end{array}$ \\
\hline A & 8 & 28 & 22 & 4 & 5 & 6.2 & 10 & 28 & 18 & 18 & 19 & 6 \\
\hline$A^{\prime}$ & 3 & 7.2 & 40 & 4 & 1.7 & 0 & 0 & 83 & 0 & 0 & 0 & 17 \\
\hline $\mathrm{B}$ & 8 & 9.7 & 57 & 2.7 & 2.9 & 2.9 & 12 & 22 & 25 & 23 & 13 & 5 \\
\hline $\mathrm{C}$ & 15 & 6.6 & 12 & 2.2 & 2.1 & 2.3 & 3 & 21 & 20 & 28 & 23 & 5 \\
\hline $\mathrm{D}$ & 5 & 2.3 & 20 & 1.4 & 1 & 0.2 & 0 & 0 & 0 & 62 & 31 & 7 \\
\hline
\end{tabular}




\section{Strategies for groundwater access}

Three main types of action were identified to face groundwater stress in both the water scarce and saline water areas (Table III). First, some farmers increased on-farm water access. In the water depleted area, farmers deepened their boreholes or drilled new ones. A Type B farmer drilled 10 boreholes on his 10 ha of land. In the areas where groundwater is both saline and scarce during summer, some farmers attempted to draw more fresh water from their wells by drilling horizontal galleries at the bottom of the well, since deepening their wells would increase salinity levels.

Second, some farmers drew water from outside their farm. They rented or purchased a patch of land where they drilled a borehole or a well, or set up a partnership with a neighbour who owned a borehole or a well. They transported the pumped water back to their land by means of pipes. In particular, farmers located on the coast had recourse to water from inland fields, and, given the increase in salinity levels, they progressively moved further inland to reach a supply of fresh water (in 2009, up to $3 \mathrm{~km}$ ). In the zone where water is scarce, where maximum depth of the base of the aquifer is $120 \mathrm{~m}$, many farmers already had several boreholes reaching the base and could thus not continue deepening them. In this situation, they often chose to draw water outside the farm. Farmers also rented or purchased other plots to cultivate where fresh water was available. These plots are located in the coastal Chaouia area and also increasingly in neighbouring regions.

The last type of action consisted in adapting the farming systems to the amount of water available on-farm given existing hydraulic equipment. In particular, some farmers grew varieties of shorter duration and that demand less water, changed sowing dates to better benefit from rain or improved land preparation techniques and irrigation equipment.

Three strategies were defined based on these types of action. Strategy $S_{1}$ involves using only available water and existing hydraulic equipment and can be described as 'adaptive' vis-àvis groundwater resources. Strategy $S_{2}$ corresponds to actions only undertaken on the farm, either obtaining more water or reducing consumption. Strategy $S_{3}$ consists in actively attempting to avoid changing the farming system by: 1) piping water in from other places; 2) renting or purchasing farm land in areas where water is still sufficient and not saline. This strategy may also involve increasing on-farm access and reducing water consumption in fields where fresh water could not be obtained in sufficient quantity. Farmers using strategy $S_{2}$ may use actions related to strategy $S_{1}$, and those using strategy $S_{3}$ may also undertake actions related to the two latter strategies: in that sense, these strategies are 'nested' (Table III). Strategies $S_{2}$ and $\mathrm{S}_{3}$, which attempt to sustain groundwater use in order to limit changing cropping patterns can be described as 'chasing' strategies vis-à-vis groundwater use (Bekkar et al., 2009). Farmers 
who adopt chasing strategies do not adapt their water use to the increasing groundwater stress, so such strategies may be considered as less sustainable, at resource level, than adaptive strategies where farmers adapt their water use to groundwater status (in terms of piezometric level or salinity rate).

Table III. Main actions used by farmers to face groundwater stress

\begin{tabular}{lll}
\hline Type of action & Water scarce area & Saline water area \\
\hline $\begin{array}{l}\text { Draw water } \\
\text { from outside }\end{array}$ & - Drill a well in a neighbouring area and pipe water back to the farm \\
the farm & - Organize a partnership with a farmer to access his well or borehole \\
$\begin{array}{l}\text { Increase on- } \\
\text { farm water }\end{array}$ & - Dent land with sufficient and non-saline groundwater \\
$\begin{array}{l}\text { access } \\
\text { Reduce on- }\end{array}$ & - Reduce irrigated crop area & - Change to salt-resistant crops \\
farm water & - Irrigate during the night & - Use fresh water for seedlings \\
consumption & - Change to shorter-duration & - Use less fertilizers \\
& varieties \\
& - Change to less water demanding & \\
& crops \\
& - Sow earlier in spring to benefit more from rainfall
\end{tabular}

Figure 2 shows the position of the five farm types in a graph where the per-ha added value of the farm activities is on the horizontal axis and the behaviour (chasing vs. adaptive) vis-à-vis groundwater on the vertical axis. Type A farmers mainly used strategy $S_{3}$. Indeed, they had sufficient capital and obtained sufficient benefits to invest in pipes to pipe in water from outside their farms. The two specialized potato farmers of Type A' rented land with sufficient groundwater to grow potatoes (i.e. they had a chasing strategy). The flower producer opted for an adaptive strategy, since he used slightly saline groundwater available on-farm and planned to invest in a desalinization plant. Type B farmers chose all three strategies. Finally, the majority of Type $C$ farmers and all Type $D$ farmers chose the adaptive strategy $S_{1}$, mainly because of lower profits from their agricultural activities and more limited capital.

Type A and D farms showed limited vulnerability to changes in groundwater resources, at least in the short term. Indeed, Type A farmers drilled new boreholes further away from the farm every time pumped water from existing boreholes became either scarce or saline. Type D 
farmers had a very limited use of groundwater, to provide some irrigation to wheat and fodder. In contrast, Type B and Type $\mathrm{C}$ farms were vulnerable to changes in groundwater resources: either they applied adaptive strategies while continuing to grow water-intensive crops or they opted for a chasing strategy, but had much less available capital than Type A farms. Type B and $\mathrm{C}$ farmers we interviewed in both water scarce and saline water areas commented that, when they chose their cropping patterns in spring, they were taking a risk with respect the water that would be available in summer.

While all Type A farms surveyed are in the top-right part of Figure 2, a dozen large-scale farms in the study area used an adaptive strategy vis-à-vis the groundwater resource (but not vis-à-vis water resources in general) because they installed a pipe to draw water from the Oum Er Rbia River. One of these farms also installed a distillation system to purify saline groundwater in order to irrigate flowers for export.

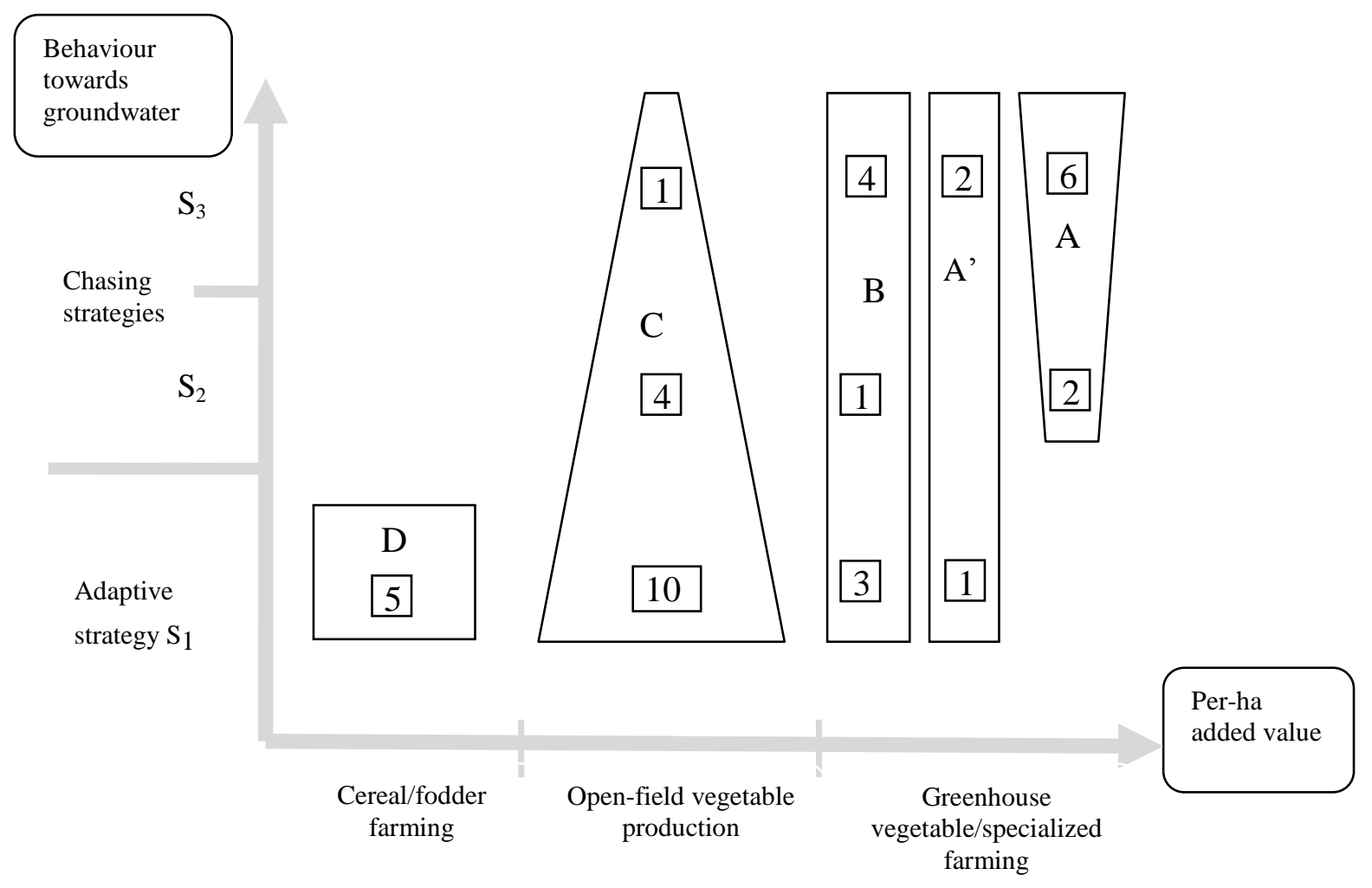

Figure 2. Farming type according to their profitability and their behaviour vis-à-vis groundwater (number of surveyed farmers indicated in squares). 
Past changes on farms and farmers' projects for the future

Crops grown on farms have changed considerably over the past 20 years (Table IV.1). In the 1990s, most farmers grew vegetables at least on part of their land, and in particular, four of the five Type D farmers used to grow vegetables. Green beans used to be grown on the coast but have almost completely disappeared in this area, because they are very sensitive to saline water. Tomato production was drastically reduced because of groundwater salinization, marketing problems and pests. During the same period, salt tolerant cauliflower appeared in the saline groundwater area. Farmers cited the main reasons for changes in their farming systems over the past 20 years: water scarcity (50\% of interviewed farmers), salinity (34\%), marketing problems due to the end of the International Trade Office intervention (26\%), floods (11\%) and crop diseases (11\%). Farmers indeed cited the groundwater crisis as the main factor of change in the area. This confirms that such past changes in cropping systems were the results of adaptive strategies. The increase in maize production reflected a strong development of cattle production. Indeed, forage crops (maize, alfalfa) are tolerant to irrigation with saline water, the proximity to Casablanca makes it easy to sell both milk and meat, and milk and meat prices are much more stable than those of vegetables. According to the main milk processing company operating in the area, milk collected by this company increased from $50 \mathrm{t} / \mathrm{d}$ in 2005 to $150 \mathrm{t} / \mathrm{d}$ in 2009 . Moreover, farmers reported that in both water scarce and saline water areas, many farmers had already left the area.

Farmers' descriptions of their future projects were divided into five main categories (Table IV.2). More than half Type A farmers planned to continue using the same farming system, even if it entailed obtaining more water with a chasing strategy. Half Type B farmers planned to rent other land (in the Chaouia zone or elsewhere) to be able to continue using the same farming system. Indeed, in zone Z2, droughts in the summer of 2006 and 2007 triggered a frenzy of drilling new boreholes. Farmers explained that they wished to go on farming in the same way as long as water was available, and that they would then move to another area to continue the same type of farming. Some Type C farmers and two-thirds of Type D farmers planned to quit agriculture. Similar trends were also observed in the activities of farmers' sons. In all Type A, A' and B families, among the sons who had already completed their education, at least one of them worked in agriculture. In half Type $\mathrm{C}$ farms, at least one of the sons who had already completed their education was involved in farming. In Type D farms, none of the sons who had already completed their education was farming, which calls into question the sustainability of such family farms. 
Table IV. Changes in crops and farms

IV.1 Past changes in main farmed crops (\% of interviewed farmers growing each crop)

\begin{tabular}{cccccc}
\hline & Tomato & Potato & Bean & Cauliflower & Maize \\
In the 1990s & 96 & 80 & 48 & 0 & 8 \\
2009 & 33 & 62 & 23 & 10 & 56
\end{tabular}

IV.2 Farmers' future projects

\begin{tabular}{|c|c|c|c|c|c|c|}
\hline Farm type & No change & $\begin{array}{c}\text { Deepen } \\
\text { existing } \\
\text { boreholes or } \\
\text { drill new } \\
\text { boreholes }\end{array}$ & $\begin{array}{c}\text { Rent new land } \\
\text { or new sources } \\
\text { of water }\end{array}$ & $\begin{array}{l}\text { Change } \\
\text { cropping } \\
\text { patterns }\end{array}$ & $\begin{array}{l}\text { Invest in } \\
\text { cattle } \\
\text { breeding }\end{array}$ & $\begin{array}{c}\text { Quit } \\
\text { farming }\end{array}$ \\
\hline A & $25 \%$ & $13 \%$ & $25 \%$ & $0 \%$ & $25 \%$ & $13 \%$ \\
\hline$A^{\prime}$ & $33 \%$ & $0 \%$ & $0 \%$ & $67 \%$ & $0 \%$ & $0 \%$ \\
\hline B & $0 \%$ & $25 \%$ & $50 \%$ & $0 \%$ & $38 \%$ & $0 \%$ \\
\hline $\mathrm{C}$ & $0 \%$ & $21 \%$ & $14 \%$ & $14 \%$ & $36 \%$ & $14 \%$ \\
\hline $\mathrm{D}$ & $40 \%$ & $0 \%$ & $0 \%$ & $0 \%$ & $0 \%$ & $60 \%$ \\
\hline
\end{tabular}

\section{DISCUSSION}

\section{Specificities of farmers' strategies}

Identified actions and strategies show both commonalities and specificities compared to other assessments of situations where farmers need to cope with water scarcity. The actions to adapt the farming system to the amount of water available on-farm were also identified in irrigation schemes where farmers face surface water scarcity (Molle et al., 2009). Moreover, in many situations of difficult groundwater access in South Asia, active groundwater markets take place (Mukherji and Shah, 2005). In Morocco, farmers make agreements to access groundwater, based on either solidarity principles or a sharing of agricultural investments (Boudjellal et al., 2011). These agreements also take place in the Chaouia, although they are not frequent. In these agreements, water is rarely sold per se, as this is generally not considered socially acceptable (Kuper et al., 2012). Finally, by contrast with the ranking of strategies of farmers facing groundwater scarcity identified by Moench (2007), Chaouia farmers initially try to remain farming, first locally and then by moving to other regions, and decide to move out of agriculture only if attempts to keep on intensive farming have failed. Indeed, Chaouia farmers have in mind 
the prosperous period of the 1980 s, where most of them successfully ventured into intensive farming.

\section{Linking farmers' strategies with second-best policies}

If no specific action is taken, farmers' projects indicate that on-going trends will continue. The adaptations made are individual (with the exception of the pipe transporting water from the Oum Er Rbia River to some large-scale farms) and most of the strategies are not economically and environmentally sustainable at the same time. Many Type A and B farms are expected to continue the same farming systems and chasing strategies, and are likely to prefer to move away from the area rather than change to adaptive strategies if they cannot obtain sufficient water. Some Type A, B and C farms may invest more in cattle breeding, which has lower water productivity than vegetables (Amghar and Jellal, 2005; Sraïri et al, 2009). Finally, Type D farms will likely not look for other agricultural alternatives, and continue with low intensity agriculture or leave the sector. Only the flower producer appeared to have a farming system that was sustainable from both farm and groundwater resource perspective (providing the disposal of effluents of his scheduled distillation plant does not contaminate groundwater resources). There is thus the need for public policies to support activities in the area that are both economically and environmentally sustainable. Such policies can be classified as water resource policies, support to farming systems and development of non-farming activities.

An important planned policy was to bring surface water to the area. However, at the time of writing (2011), the project was uncertain, among other reasons because, given the overallocation of Oum Er Rbia River basin water resources, the amount of water allocated to the scheme would not be secured in periods of drought (Faysse et al., 2012). For farms with high water productivity (e.g., Types A, A' and B) located close to the coast, the use of desalinization plants may be an opportunity.

Policies could support the adaptation of farming systems to groundwater stress. First, groundwater use efficiency can be improved. To assess the potential for improvement, drip irrigation practices were analyzed on 16 farms (El Fennani, 2009). Farmers over-irrigate by more than twice the required amount of water both due to heterogeneity in distribution and general over-irrigation, causing respectively an increase of $46 \%$ and $64 \%$ compared to theoretical water demand. A more homogeneous irrigation network would enable farmers to grow more crops with the same quantity of pumped water. However, during the average growth cycle of the crops, farmers do not over-irrigate (given existing heterogeneity in distribution), so improved irrigation planning would enable a decrease in production costs and in impacts on groundwater resources but would not enable more crops to be grown with the same amount of 
pumped water. Moreover, the majority of farmers consider their drip irrigation systems and practices are satisfactory and do not think that there is room for improvement of irrigation efficiency. Therefore, while opportunities for such improvement do exist, the way to communicate them with farmers will require specific attention.

Second, policies could support more productive use of water, i.e., an increase in profits per cubic metre of pumped water. In the study area, apart from some niche products, vegetables provide the highest profits per cubic metre of water withdrawn. Thus, policies could give priority to vegetables over forage for milk and meat production, but this would require providing major incentives to limit the current trends towards more cattle breeding. Improving marketing on the national market or reshuffling export channels would lead to better prices for the vegetables produced. However, any policy that increases the profits made from vegetables is also likely to increase incentives for farmers to maintain chasing strategies, or even shift from adaptive to chasing strategies. In other words, farms that are both profitable and sustainable visà-vis groundwater resources are situated in the bottom right part of Figure 2, but such policies would lead farms to maintain or move to the upper right part of the figure.

A third policy could be to develop intensive agriculture involving limited use of groundwater. Beside the two previously-mentioned projects, the regional agricultural strategy has scheduled actions to support the production of chicken and beef, which are less dependent on groundwater resources (rainfed maize for cattle feed is commonly produced in the region during spring), in both water scarce and saline water areas. However, poultry production requires meeting many legal norms and making high investments, which makes it difficult for small-scale farmers. Moreover, in the saline water area, providing animals with fresh water has to be catered for. In several villages in the vicinity of Bir Jdid city (zone Z3), the groundwater is saline and to water their cattle, villagers purchase fresh water from trucks at high costs. They have already actively attempted to get connected to rural drinking water networks in order to reduce the cost of watering their cattle.

A last policy option would be to develop non-agricultural activities, such as tourism on the coast in the north-east part of the study area. However, while young men can provide the necessary labour for the building of the resorts, they do have not the qualifications to find work there once the resorts are up and running (this is what happened during and after the construction of a large tourist resort south of Azemmour). There would be a need to ensure specific capacity-building for young people of both sexes. 


\section{CONCLUSION}

This analysis revealed the diversity of strategies farmers apply when confronted with groundwater stress, in an area where the aquifer has limited depth. While, in deep aquifers, farms are differentiated because of their different capacities to drill ever deeper boreholes, in relatively shallow aquifers, strategies are more horizontal: Many farmers face the groundwater crisis by attempting to 'chase' groundwater outside their farms, either by piping it to their fields or by renting land in an area with more (or less saline) groundwater. While farm-level actions to cope with groundwater scarcity and salinity differed, farmers' strategies to face both types of groundwater stress could be classified in the same way in the two areas as either chasing or adaptive strategies. If current trends continue, the groundwater crisis will continue to impacting above all small-scale farmers and will widen the gap between them and larger-scale farmers, who have more means to cope with groundwater stress.

A wide range of policies could be defined to address the groundwater crisis. These differ in terms of the difficulty of implementing them and the type of farms that may benefit from them (either all farms or only capital intensive ones). In a situation where there is no control over groundwater use and cropping patterns, short-term policies to improve water productivity may also reinforce chasing strategies, which are less sustainable than adaptive strategies with respect to groundwater. Supporting adaptation of rural territories to a groundwater crisis in a situation with a lack of institutional means to limit water use may thus be described as a 'wicked problem' (Rittel and Weber, 1973), with no perfect formulation of the problem and no first-best solution. Mixes of second-best policies may be required. In particular, policies to better adapt the farming systems to the groundwater crisis, which can be implemented in the short-term, could be combined with longer-term policies that support farmers' partial or complete shift towards activities with fewer impacts on groundwater resources, such as bringing in surface water, desalinization plants, soilless agriculture and non-agricultural initiatives.

\section{ACKNOWLEDGMENTS}

The study was conducted as part of the Aquimed project, funded in the framework of the Eranet Circle-Med initiative by the French Ministry of Ecology, Energy and Sustainable Development and the Portuguese Foundation for Science and Technology. 


\section{REFERENCES}

Amghar S, Jellal J. 2005. La valorisation de l'eau d'irrigation par les productions végétales dans le périmètre irrigué de Doukkala. Ingénieries, 41.

Bahir M, Mennani A. 2002. Problématique de la gestion des eaux souterraines au Maroc. Estudios Geológicos, 58.

Bekkar Y, Kuper M, Errahj M, Faysse N, Gafsi M. 2009. On the difficulty of managing an invisible resource: farmers' strategies and perceptions of groundwater use, field evidence from Morocco. Irrigation and Drainage, 58.

Boudjellal AA, Bekkar Y, Kuper M, Errahj M, Hammani A, Hartani T. 2011. Analyse des arrangements informels pour l'accès à l'eau souterraine sur les périmètres irrigués de la Mitidja (Algérie) et du Tadla (Maroc). Cahiers Agriculture. 20. doi: 10.1684/agr.2010.0458

Bouregreg-Chaouia Catchment Management Agency, 2010. Water resources in the Bouregreg Chaouia Catchment Management Agency area: the case of the coastal Chaouia Aquifer. Presentation made to Aquimed seminar, El Jadida, June, $7^{\text {th }}$.

Doukkala-Abda Regional Direction of Agriculture, 2010. Plan agricole régional, région des Doukkala Abda. El Jadida, Morocco: Unpublished document.

El Fennani, O. 2009. Analyse et diagnostic de la mise en place et de la pratique d'irrigation localisée dans la zone de la Chaouia côtière. Master Degree Thesis. IAV Hassan II: Rabat.

Fakir Y, Zerouali A, Aboufirassi M, Bouabdelli M. 2001. Exploitation et salinité des aquifères de la Chaouia Côtière, littoral atlantique, Maroc. Journal of African Earth Sciences, 32.

Faysse N, El Amrani M, El Aydi S, Lahlou A. 2012. Formulation and implementation of policies to deal with groundwater overuse in Morocco: which supporting coalitions? To appear in Irrigation and Drainage.

Gafsi M. 2007. Gestion stratégique et choix des investissements. In Exploitations agricoles familiales en Afrique de l'Ouest et du Centre, Gafsi M, Dugué P, Jamin JY, Brossier J (eds). Quae: Versailles, France.

Giordano M. 2009. Global Groundwater? Issues and Solutions. Annual Review of Environment and Resources, 34.

Kuper M, Hammani A, Chohin A, Garin P, Saaf M. 2012. When groundwater takes over: Linking 40 years of agricultural and groundwater dynamics in a large-scale irrigation scheme in Morocco.To appear in Irrigation and Drainage. 
Moench M. 2007. When the well runs dry but livelihood continues: adaptive responses to groundwater depletion and strategies for mitigating the associated impacts. In The Agricultural Groundwater Revolution: Opportunities and Threats to Development, Giordano M, Villholth KG (eds). CABI Head Office: Oxford, UK.

Molle F, Venot JP, Lannerstad M, Hoogesteger J. 2009. Villains or heroes? Farmers' adjustments to water scarcity. Irrigation and Drainage, 58.

Moustadraf J, Razack M, Sinan M. 2008. Evaluation of the impacts of climate changes on the coastal Chaouia aquifer, Morocco, using numerical modeling. Hydrogeology Journal, 16.

Mudrakartha S. 2007. To adapt or not to adapt: The dilemma between long-term resource management and short-term livelihood. In The Agricultural Groundwater Revolution: Opportunities and Threats to Development, Giordano M, Villholth KG (eds). CABI Head Office: Oxford, UK.

Mukherji A. 2006. Political ecology of groundwater: the contrasting case of water-abundant West Bengal and water-scarce Gujarat, India. Hydrogeology Journal, 14.

Mukherji A, Shah T. 2005. Groundwater socio-ecology and governance: a review of institutions and policies in selected countries. Hydrogeology Journal, 13.

Oweis T, Hachum A, Kijne J. 1999. Water harvesting and supplemental irrigation for improved water use efficiency in dry areas. SWIM Paper 7. International Water Management Institute, Colombo.

Prakash A. 2005. The dark zone: Groundwater irrigation, politics and social power in North Gujarat. $\mathrm{PhD}$ thesis, water resources series. Wageningen University; Wageningen.

Qureshi AS, Gill MA, Sarwar A. 2010. Sustainable groundwater management in Pakistan: challenges and opportunities. Irrigation and Drainage, 59.

Rittel HWJ, Webber MM. 1973. Dilemmas in a general theory of planning. Policy Sciences, 4.

Shah T. 2009. Taming the Anarchy: Groundwater Governance in South Asia. Washington, DC: Resources for the Future Press.

Sraïri, MT, Rjafallah M, Kuper M, Le Gal PY. 2009. Water productivity through dual purpose (milk and meat) herds in the Tadla irrigation scheme, morocco. Irrigation and Drainage, 58 .

Younsi A. 2001. Incidences de pluies exceptionnelles sur un aquifère libre côtier en zone semiaride. Revue des sciences de l'eau, 14. 